\title{
Foliar Application of Micro Silica, Potassium Chloride and Calcium Chloride Enhances Yield and Fruit Quality of Balady Orange Tree
}

\author{
EmadEldin H.Abd-Elall ${ }^{1}$ and Mohamed A. Hussein
}

\begin{abstract}
This work was done to study the influences of foliar application with micro silicon alone or combined with potassium chloride and Calcium chloride $\left(\mathrm{CaCl}_{2}\right)$ on leaf meaner contents, yield and fruit quality of Balady orange trees during two successive seasons 2015 and 2016 conducted in the experimental farm, faculty of Agriculture, Al Kawamell, Sohag University. The results indicated that foliar spraying of Balady orange trees with micro silicon alone or combined with potassium chloride (KCl)and Calcium chloride $\left(\mathrm{CaCl}_{2}\right)$ increased yield and Fruit physical and Chemical properties such as TSS, V.C. and TSS/Acid ratio compare to the control. All treatments spraying with micro silica alone or combined with potassium chloride and calcium chloride were significantly increased yield and fruit quality (except micro silica at $0.025 \%$ and micro silica at $0.025 \%+\mathrm{CaCl}_{2}$ at $2 \%$ in both seasons) and leaf meaner contents as compared with the control treatment. The highest value was observed with the trees sprayed with micro silica at $0.1+$ potassium chloride at $2 \%+$ calcium chloride at $2 \%$ in both seasons respectively, flowed by the treatment sprayed with micro silica at $0.1 \%$ + potassium chloride at $2 \%$ in both seasons. The lowest values were obtained by the control treatment in both seasons.
\end{abstract}

Keywords: micro silicon, potassium chloride, Calcium chloride, yield, fruit quality, Balady orange trees.

\section{INTRODUCTION}

Citrus is one of the most important fruit crops in the world. Orange is the most abundant citrus fruit accounting for about third of the world's citrus production, followed by mandarin, grapefruit, and lemon. In Egypt citrus is ranked first in terms of cultivated area and productivity, where orange occupies $85 \%$ of the area of citrus fruit. The total cultivated area of citrus in Egypt reached 530,415 feddan (feddan = $4200 \mathrm{~m}^{2}$ ) producing about $4,396,855$ tons with productivity of 8.2 tons/feddan (according to the latest statistics of the ministry of agriculture (2014). Environmental conditions in Egypt, are favorable to citrus production and thus there are sufficient amounts for local consumption and for foreign export markets. Heat stress and salt stress highly affect the yield and fruit quality of orange especially in reclaimed soils. Such stresses decrease vegetative growth, yield and fruit

\footnotetext{
${ }^{1}$ Horticulture Department, Faculty of Agriculture, Sohag University, Sohag, Egypt.

E-Mail: kkk9932001@yahoo.co.uk

Received June 26, 2018, Accepted July 31, 2018
}

size. These problems can be overcome by addition of some elements such as silicon, potassium and calcium.

About 210-224 million tons of silicon is removed from the arable soils all around the world and soils become low in available silicon content (reports of FAO). The positive effects of silicon on the growth and development of crops is reported by many researchers (Guntzer et al. 2012; Korndorfer and Lepsch, 2001؛ Ma, 2004; Meena et al. 2014 and Chanchal et al. 2016; Elkhatib et al.2017).The use of all silicon sources has been very effective in improving yield and fruit quality in various fruit crops (Al-Wasfy 2014, El-Khawaga and Mansour 2014, and Abd El-Wahab 2015).Silicon plays an important role in increasing and enhancing fruit crops to biotic and abiotic stresses, nutrient and water uptake, photosynthesis, plant pigments synthesis and cell division (Epstein 1999 and Ma 2004).Silicon is concentrated in skin tissue as a thin layer of cellulose silicon membrane. In this way thus it can protect and strengthen the mechanical structure of the plant (Ma2003).

Potassium is essential for the growth of citrus trees and yield, and many different plant biological processes. Potassium is easily transported through citrus trees and can be involved in the transport of carbohydrates and metabolism. Potassium is used as an osmosis agent in opening and closing stomata, an important mechanism of water uptake and usage. Potassium also neutralizes organic acids and plays a role in controlling the acidity and $\mathrm{pH}$ of fruit juice (Mullins et al., 1992). Potassium chloride, also, reduces the negative effects of salt stress, and compete the sodium chloride salt. As a consequence, sodium chloride uptake is reduced.

Calcium a macro nutrient, is essential element for plant growth and development, and is considered as an important intracellular messenger, mediating responses to hormones, stress signals and a variety of developmental processes. Besides, calcium it is an integral part in the structure of cell wall and cellular membrane (Hepler and Winship, 2010). Moreover, it plays a pivotal role in resistance to bacterial and viral diseases (Hepler, 2005). However, calcium is an immobile element and thus the plants need a continuous supply of calcium for strong vegetative growth (Del 
Amor and Marcelis, 2003) which can be accomplished through foliar application of calcium.

The objective of this study was to investigate the impact of foliar application with micro silicon alone/or combined with potassium chloride and Calcium chloride $\left(\mathrm{CaCl}_{2}\right)$ on yield and fruit quality of Balady orange tree.

\section{MATERIALS AND METHODS}

This study was conducted in the experimental farm, faculty of Agriculture, al Kawamell, Sohag University, Egypt during 2015and 2016 seasons. Thirty nine trees (14 years old) were budded on Volkameriana lemon (Citrus volkameriana L.) rootstock grown in sandy soil. The trees are planted at $5 \times 5$ meters apart and received adequate-fertilizers, irrigated using drip irrigation system and subjected to the same cultural practices that were followed in the orchard. The chosen trees are nearly similar in growth vigor and healthy. Micro silicon amorphous $\mathrm{SiO} 2$ (Elkem, Norway), alone or combined with potassium chloride $(\mathrm{KCl})$ and Calcium chloride $\left(\mathrm{CaCl}_{2}\right)$ (shoura Co. chemicals) were sprayed. Eleven treatments were applied as follows Control (water only), micro silica at $0.025 \%$, micro silica 0.05 $\%$, micro silica at $0.1 \%$, micro silica at $0.025 \%+\mathrm{KCl}$ at $2 \%$, micro silica $0.05 \% .+\mathrm{KCl}$ at $2 \%$, micro silica at $0.1 \% .+\mathrm{KCl}$ at $2 \%$, micro silica at $0.025 \%+\left(\mathrm{CaCl}_{2}\right)$ at $2 \%$, micro silica $0.05 \%+\left(\mathrm{CaCl}_{2}\right)$ at $2 \%$, micro silica at $0.1 \%+\left(\mathrm{CaCl}_{2}\right)$ at $2 \%$, micro silica at $0.025 \%+\mathrm{KCl}$ at 2 $\%+\left(\mathrm{CaCl}_{2}\right)$ at $2 \%$, micro silica $0.05 \%+\mathrm{KCl}$ at $2 \%+$ $\left(\mathrm{CaCl}_{2}\right)$ at $2 \%$, micro silica at $0.1 \%+\mathrm{KCl}$ at $2 \%+$ $\left(\mathrm{CaCl}_{2}\right)$ at $2 \%$.All treatments were sprayed at three successive times, the $1^{\text {st }}$ spray after fruit set, the 2 nd spray on the middle of May and the $3^{\text {rd }}$ on middle of July.

\section{Measurements}

Leaf mineral content. Leaves were collected to determine leaf content of $\mathrm{N}, \mathrm{P}, \mathrm{K}$ and $\mathrm{Ca}$ and $\mathrm{Si}$ on leaf dry weight basis. In the dry petioles, leaf content of $\mathrm{N}$, $\mathrm{P}, \mathrm{K}$ and $\mathrm{Ca}$ (as percentages) were determined according to Wilde et al. (1985). Silicon content was analyzed using a spectrophotometric method at a 660 $\mathrm{nm}$ wavelength (Elliot and Snyder, 1991).

\section{Measurements of yield}

Harvesting was achieved during the regular commercial harvesting time under sohag Governorate conditions (at last week of December); yield expressed in weight and number of fruits per tree was recorded. The number of fruits per tree was counted at the harvesting time (last week of December) the yield per tree $(\mathrm{Kg})$ was determined as well.

\section{a- Fruit physical properties}

Twenty fruits were taken at harvest time from each treated tree to determine fruit weight $(\mathrm{g})$, fruit weight data was computed by considering average weight of five fruits and expressed in grams. Fruit height $(\mathrm{cm})$, fruit width $(\mathrm{cm})$ and peel weight $(\mathrm{g})$.

\section{b- Chemical analysis}

Total soluble solids (T.S.S \%) was determined by using Zeiss hand refractometer.

Total acidity (\%) was determined in fruit juice as anhydrous citric acid according to A.O.A.C, (1995).

Total soluble solids/acid ratio was calculated from the values of total soluble solids divided by values of total acids.

Ascorbic acid (Vitamin C) was calculated as mg/100 ml juice according to Horwitz, (1972).

Statistical analysis: Randomized complete block design with three replicates per treatment and one tree per replicate was used. Statistical analysis was done and treatment means were compared using new L.S.D. at 5\% (Mead et al., (1993)

\section{RESULTS AND DISCUSSION}

\section{Yield/tree, fruit weight and number of fruit/tree}

Table (1) showed that all treatment spraying with micro silica alone or combined with potassium chloride and calcium chloride were significant to increase yield (except MS at $0.025 \%$ in both seasons and micro silica at $0.025 \%+\mathrm{CaCl}_{2}$ at $2 \%$ in the first season) as compared with the control treatment. The highest value observed with the trees sprayed with micro silica at $0.1+$ potassium chloride at $2 \%+$ calcium chloride at $2 \%$ in the two seasons respectively. Flowed by the treatment sprayed with micro silica at $0.1+$ potassium chloride at $2 \%$ in both seasons. The lowest values obtained that the control treatment in both seasons. The increase in the yield due to spray micro silica can be explained bases of Silicon plays an important role in increasing and enhancing of balady orange tree to biotic and a biotic stresses, nutrient and water uptake, photosynthesis, and all cell division. The findings regarding the promoting effect of silicon on yield are in harmony with those obtained by Gad El-Kareem(2012), Al-Wasfy (2014), El-Khawaga (2014), El-Khawaga and Mansour (2014),Gad El-Kareem et al. (2014) and Abd El-Wahab (2015).

A significant increase in fruit weight was obtained in both seasons by all different foliar application (except micro silica at $0.025 \%$ and micro silica at $0.025 \%+$ $\mathrm{CaCl}_{2}$ at $2 \%$ in both seasons and micro silica $0.05 \%$ in the second season) compare to the control treatment. Increase concentration of micro silica alone or 
combined with potassium chloride and calcium chloride lead to increase fruit weight. Treatments with micro silica combined with potassium chloride give the highest increase in fruit weight than treatments with micro silica combined with calcium chloride. The highest value observed with the trees sprayed with micro silica at $0.1+$ potassium chloride at $2 \%+$ calcium chloride at $2 \%$ in both seasons respectively, while, the lowest values were recorded the control treatment in both seasons. The increase in the fruit weight caused by spray micro silica due to Silicon plays an important role in increasing and enhancing of balady orange tree to biotic and a biotic stresses, nutrient and water uptake, photosynthesis, and all cell division. The findings regarding the promoting effect of silicon on yield are in line with those obtained by Gad El-Kareem(2012), AlWasfy (2014), El-Khawaga (2014), El-Khawaga and Mansour (2014), Gad El-Kareem et al. (2014) and Abd El-Wahab (2015).

The increase in fruit number was not significant of all treatments in the first season, while in the second season the increase in fruit number was significant for all different foliar application(except micro silica at $0.025 \%$ and micro silica at $0.025 \%+\mathrm{CaCl}_{2}$ at $2 \%$ in both seasons) as compared with the control treatment. The maximum values were recorded for the trees sprayed with micro silica at $0.1 \%+$ potassium chloride at $2 \%+$ calcium chloride at $2 \%$ in both seasons respectively. While, the lowest value obtained that the control treatment in both seasons. Silica role in

Table 1. Effect of Foliar Application of micro silica, potassium chloride and calcium chloride on Yield/tree, fruit weight, number of fruit/tree, Fruit Height $(\mathrm{cm})$ and fruit width $(\mathrm{cm})$

\begin{tabular}{|c|c|c|c|c|c|c|c|c|c|c|}
\hline \multirow[t]{2}{*}{ Treatment } & \multicolumn{2}{|c|}{$\begin{array}{l}\text { No. of } \\
\text { fruits/tree }\end{array}$} & \multicolumn{2}{|c|}{$\begin{array}{c}\text { fruit weight } \\
\text { (g.) }\end{array}$} & \multicolumn{2}{|c|}{$\begin{array}{l}\text { Yield/tree } \\
\text { (Kg.) }\end{array}$} & \multicolumn{2}{|c|}{$\begin{array}{l}\text { Fruit height } \\
\text { (cm) }\end{array}$} & \multicolumn{2}{|c|}{$\begin{array}{l}\text { Fruit width } \\
\text { (cm) }\end{array}$} \\
\hline & 2015 & 2016 & 2015 & 2016 & 2015 & 2016 & 2015 & 2016 & 2015 & 2016 \\
\hline Control & 109 & 102.7 & 195 & 200.0 & 21.26 & 20.54 & 6.8 & 6.8 & $6 . .6$ & 6.5 \\
\hline MS at $0.025 \%$ & 113 & 113 & 200.0 & 205.0 & 22.60 & 23.16 & 7.10 & 7.20 & 6.8 & 6.7 \\
\hline MS $0.05 \%$ & 122 & 122 & 214.0 & 213.3 & 25.62 & 25.17 & 7.25 & 7.25 & 6.9 & 7.2 \\
\hline $\mathrm{MS}$ at $0.1 \%$ & 125.3 & 123.3 & 220.0 & 221.7 & 27.6 & 27.93 & 7.30 & 7.30 & 7.1 & 7.1 \\
\hline $\mathrm{MS}$ at $0.025 \%+\mathrm{KCl}$ at $2 \%$ & 115 & 116 & 210 & 213.3 & 24.82 & 25.44 & 7.30 & 7.24 & 7.0 & 7.0 \\
\hline $\mathrm{MS}$ at $0.05 \%+\mathrm{KCl}$ at $2 \%$ & 21.6 & 128 & 218.3 & 223.3 & 28.44 & 28.45 & 7.30 & 7.30 & 7.1 & 7.3 \\
\hline $\mathrm{MS}$ at $0.1 \%+\mathrm{KCl}$ at $2 \%$ & 129.6 & 130 & 228.3 & 228.3 & 29.58 & 29.68 & 7.50 & 7.70 & 7.2 & 7.3 \\
\hline $\mathrm{MS}$ at $0.025 \%+\mathrm{CaCl}_{2}$ at $2 \%$ & 115 & 113 & 203.3 & 211.3 & 23.37 & 24.51 & 7.10 & 7.00 & 6.8 & 6.6 \\
\hline $\mathrm{MS}$ at $0.05 \%+\mathrm{CaCl}_{2}$ at $2 \%$ & 125.6 & 122 & 215.0 & 222.3 & 26.36 & 26.63 & 7.10 & 7.20 & 6.9 & 6.9 \\
\hline $\mathrm{MS}$ at $0.1 \%+\mathrm{CaCl}_{2}$ at $2 \%$ & 127.7 & 128 & 222.7 & 222.3 & 27.35 & 27.53 & 7.40 & 7.40 & 7.2 & 7.2 \\
\hline $\begin{array}{l}\mathrm{MS} \text { at } 0.025 \%+\mathrm{KCl} \text { at } 2 \\
\%+\mathrm{CaCl}_{2} \text { at } 2 \%\end{array}$ & 125.6 & 128 & 218.3 & 218.7 & 27.42 & 27.99 & 7.40 & 7.24 & 7.0 & 7.0 \\
\hline $\begin{array}{l}\mathrm{MS} \text { at } 0.05 \%+\mathrm{KCl} \text { at } 2 \\
\%+\mathrm{CaCl}_{2} \text { at } 2 \%\end{array}$ & 129 & 128.7 & 223.3 & 222.0 & 28.80 & 28.57 & 7.50 & 7.60 & 7.2 & 7.2 \\
\hline $\begin{array}{l}\mathrm{MS} \text { at } 0.1 \%+\mathrm{KCl} \text { at } 2 \%+\mathrm{CaCl}_{2} \\
\text { at } 2 \%\end{array}$ & 131.7 & 130.3 & 235.7 & 233.7 & 31.04 & 30.45 & 7.80 & 7.90 & 7.2 & 7.4 \\
\hline New L.S.D at $5 \%$ & NS & 15.82 & 13.68 & 21.33 & 3.49 & 3.61 & 0.41 & 0.44 & 0.58 & 0.72 \\
\hline
\end{tabular}

reinforcing plants for being tolerant to different environmental stress such as salinity, drought and alleviating both biotic and a biotic stress which could be reflected positively on both growth and fruiting activities. Also, our results are in harmony with those found by Ibrahim and Al-Wasfy 2014 on Valencia orange and Thippeshppa, et al., (2014) on Sapota who suggested that silicon sources like potassium chloride silicate significantly increased number of fruits per tree and fruit yield.

\section{Fruit height, fruit width and peel weight}

Table (1) revealed that all treatments spraying with micro silica alone or combined with potassium chloride and calcium chloride were significantly increased fruit height and width (except micro silica at $0.025 \%$, micro silica at $0.025 \%+\mathrm{CaCl}_{2}$ at $2 \%$ and micro silica at $0.05 \%+\mathrm{CaCl}_{2}$ at $2 \%$ in both seasons) as compared with the control treatment. The best results with regard to fruit height and width were obtained when the trees were sprayed with micro silica at $0.1 \%+$ potassium chloride at $2 \%+$ calcium chloride at $2 \%$ in both seasons respectively. While, the lowest values obtained that the control treatment in the two seasons. These results reveal a positive relationship that can arise between Fruit height and fruit width and foliar spray of potassium chloride the present results are in a general harmony with Zaied et al., (2006) on Navel orange, who mentioned that, fruit size increase with increasing the level of applied potassium chloride. 
The increase in peel weight for trees spray with calcium could be attributed to that such an element is considered as an important component in the structure of cell walls and cellular membranes. The findings regarding the promoting effect of calcium on peel weight are in harmony with those obtained by (Hepler and Winship, 2010).

\section{Fruit chemical properties:}

Table (2) reveals that treating the trees with micro silica alone or combined with potassium chloride and calcium chloride was significantly very effective in improving fruit quality in terms of increasing fruit content in T.S.S \% (except micro silica at $0.025 \%$ and micro silica at $0.025 \%+\mathrm{CaCl}_{2}$ at $2 \%$ in both seasons), $\mathrm{T} \mathrm{S}$ S/Acid ratio (only significant treatments were micro silica at $0.1 \%+\mathrm{KCl}$ at $2 \%$, micro silica at $0.05 \%+\mathrm{KCl}$ at $2 \%+\mathrm{CaCl}_{2}$ at $2 \%$ and $\mathrm{MS}$ at $0.1 \%+\mathrm{KCL}$ at $2 \%+$ $\mathrm{CaCl}_{2}$ at $2 \%$ ) and vitamin $\mathrm{C}$, in fruits Balady orange trees compared to those of control treatment. The promotion was significantly related to the increase in concentrations of micro silica alone or combined with potassium chloride and calcium chloride. Using micro silica combined with potassium chloride significantly improved fruit quality than using micro silica combined with calcium chloride. Using micro silica combined with potassium chloride and calcium chloride was

Table 2. Effect of Foliar Application of micro silica, potassium chloride and calcium chloride on Rind weight (g.), Fruit juice TSS\%, Fruit juice acidity \%, TSS /acid ratio and Fruit juice V.C mg/100g

\begin{tabular}{|c|c|c|c|c|c|c|c|c|c|c|}
\hline \multirow[t]{2}{*}{ Treatment } & \multicolumn{2}{|c|}{$\begin{array}{l}\text { Rind weight } \\
\text { (g.) }\end{array}$} & \multicolumn{2}{|c|}{$\begin{array}{c}\text { Fruit juice } \\
\text { TSS\% }\end{array}$} & \multicolumn{2}{|c|}{$\begin{array}{c}\text { Fruit juice } \\
\text { acidity \% }\end{array}$} & \multicolumn{2}{|c|}{$\begin{array}{c}\text { TSS / } \\
\text { acid ratio }\end{array}$} & \multicolumn{2}{|c|}{$\begin{array}{c}\text { Fruit juice } \\
\text { V.C mg/100g }\end{array}$} \\
\hline & 2015 & 2016 & 2015 & 2016 & 2015 & 2016 & 2015 & 2016 & 2015 & 2016 \\
\hline Control & 39.3 & 38.0 & 11.9 & 11.4 & 0.992 & 0.956 & 11.99 & 11.92 & 33 & 34.5 \\
\hline MS at $0.025 \%$ & 39.7 & 38.7 & 12.1 & 12.4 & 0.917 & 0.930 & 13.19 & 13.33 & 44.3 & 42.7 \\
\hline MS $0.05 \%$ & 40.7 & 41.0 & 12.8 & 13.1 & 0.864 & 0.870 & 14.81 & 15.05 & 43.7 & 51 \\
\hline MS at $0.1 \%$ & 41.3 & 41 & 12.8 & 12.9 & 0.981 & 0.970 & 13.05 & 13.29 & 48 & 49.7 \\
\hline $\mathrm{MS}$ at $0.025 \%+\mathrm{KCl}$ at $2 \%$ & 40.3 & 39.7 & 12.5 & 13.1 & 0.880 & 0.860 & 14.20 & 15.23 & 45.3 & 47.3 \\
\hline $\mathrm{MS}$ at $0.05 \%+\mathrm{KCl}$ at $2 \%$ & 41.3 & 41.0 & 12.7 & 12.8 & 0.960 & 0.953 & 13.23 & 13.43 & 47.7 & 49.7 \\
\hline $\mathrm{MS}$ at $0.1 \%+\mathrm{KCl}$ at $2 \%$ & 42.7 & 43.3 & 13.4 & 13.5 & 0.747 & 0.730 & 17.94 & 18.49 & 54 & 53.0 \\
\hline MS at $0.025 \%+\mathrm{CaCl}_{2}$ at $2 \%$ & 40.3 & 40.3 & 12.1 & 12.2 & 0.907 & 0.930 & 13.34 & 13.12 & 44.3 & 44.7 \\
\hline MS at $0.05 \%+\mathrm{CaCl}_{2}$ at $2 \%$ & 41 & 40.7 & 12.4 & 12.5 & 0.907 & 0.920 & 13.67 & 13.5 & 45.7 & 47.3 \\
\hline $\mathrm{MS}$ at $0.1 \%+\mathrm{CaCl}_{2}$ at $2 \%$ & 42.3 & 42.0 & 13.2 & 13.3 & 0.812 & 0.850 & 16.26 & 15.64 & 49 & 52.7 \\
\hline $\begin{array}{l}\mathrm{MS} \text { at } 0.025 \%+\mathrm{KCl} \text { at } 2 \\
\%+\mathrm{CaCl}_{2} \text { at } 2 \%\end{array}$ & 42.7 & 41 & 12.9 & 12.9 & 0.885 & 0.865 & 14.57 & 14.91 & 49.7 & 50.6 \\
\hline $\begin{array}{l}\mathrm{MS} \text { at } 0.05 \%+\mathrm{KCl} \text { at } 2 \%+ \\
\mathrm{CaCl} 2 \text { at } 2 \%\end{array}$ & 42.7 & 43 & 13.4 & 13.1 & 0.760 & 0.780 & 17.63 & 16.79 & 51 & 52.3 \\
\hline $\begin{array}{l}\mathrm{MS} \text { at } 0.1 \%+\mathrm{KCl} \text { at } 2 \%+ \\
\mathrm{CaCl}_{2} \text { at } 2 \%\end{array}$ & 43.7 & 43.7 & 13.5 & 13.7 & 0.742 & 0.755 & 18.19 & 18.14 & 51.7 & 53.0 \\
\hline New L.S.D at $5 \%$ & NS & 5.78 & 0.43 & 1.16 & NS & NS & 5.35 & 5.03 & 7.06 & 5.20 \\
\hline
\end{tabular}

significantly preferable than using micro silica alone, micro silica combined with potassium chloride and micro silica combined with calcium chloride in improving fruit quality. Spraying micro silica at $0.1 \%+$ potassium chloride at $2 \%+$ calcium chloride at $2 \%$ in the two seasons gave the highest values of T.S.S \%, T.S.S/Acid ratio and vitamin C compared with the other treatments. Control treatment gave the lowest values in such fruit chemical properties in both seasons.

The effect of foliar application with micro silica alone or combined with potassium chloride and calcium chloride on Fruit juice acidity \% was not significant in both seasons. The improving Fruit chemical properties due to spray the tree with micro silica alone or combined with potassium chloride and calcium chloride could be attributed to Silicon which plays an important role in increasing and enhancing of balady orange tree to nutrient, water uptake and photosynthesis, moreover, potassium chloride may be involved in carbohydrate transport and metabolism. Potassium, a cation, is used as an osmotic agent in the opening and closing of stomata, an important mechanism of orange tree water relations. Potassium also neutralizes organic acids and plays a role in controlling acidity and $\mathrm{pH}$ of the fruit's juice the findings regarding the promoting effect of 
Table 3. Effect of Foliar Application of micro silica, potassium chloride and calcium chloride on Si \%, N \% K $\%, \mathrm{P} \%$ and $\mathrm{Ca} \%$

\begin{tabular}{|c|c|c|c|c|c|c|c|c|c|c|}
\hline \multirow[b]{2}{*}{ Treatment } & \multicolumn{2}{|c|}{ Si \% } & \multicolumn{2}{|c|}{$\mathbf{N \%}$} & \multicolumn{2}{|c|}{ K \% } & \multicolumn{2}{|c|}{$\mathbf{P} \%$} & \multicolumn{2}{|c|}{ Ca \% } \\
\hline & $\begin{array}{c}201 \\
6\end{array}$ & 2015 & 2016 & $\begin{array}{c}201 \\
5\end{array}$ & 2015 & $\begin{array}{c}201 \\
6\end{array}$ & 2015 & 2016 & $\begin{array}{c}201 \\
5\end{array}$ & 2016 \\
\hline Control & 1.17 & 1.18 & 2.30 & 2.35 & 1.27 & 130 & 0.21 & 0.22 & 1.89 & 1.93 \\
\hline MS at $0.025 \%$ & 1.24 & 1.22 & 2.35 & 2.38 & 1.35 & 140 & 0.22 & 0.24 & 1.95 & 1.97 \\
\hline MS $0.05 \%$ & 1.25 & 1.27 & 2.44 & 2.47 & 1.42 & 145 & 0.26 & 0.28 & 2.03 & 2.07 \\
\hline MS at $0.1 \%$ & 1.38 & 1.40 & 2.50 & 2.55 & 1.53 & 155 & 0.34 & 0.38 & 2.15 & 2.16 \\
\hline $\mathrm{MS}$ at $0.025 \%+\mathrm{KCl}$ at $2 \%$ & 1.24 & 1.26 & 2.39 & 2.40 & 1.41 & 148 & 0.25 & 0.30 & 2.03 & 2.1 \\
\hline $\mathrm{MS}$ at $0.05 \%+\mathrm{KCl}$ at $2 \%$ & 1.28 & 1.27 & 2.49 & 2.52 & 1.75 & 166 & 0.34 & 0.40 & 2.08 & 2.17 \\
\hline $\mathrm{MS}$ at $0.1 \%+\mathrm{KCl}$ at $2 \%$ & 1.40 & 1.38 & 2.53 & 2.58 & 1.81 & 168 & 0.36 & 0.44 & 2.16 & 2.18 \\
\hline MS at $0.025 \%+\mathrm{CaCl}_{2}$ at $2 \%$ & 1.23 & 1.22 & 2.35 & 2.40 & 1.39 & 1.45 & 0.23 & 0.25 & 2.16 & 2.20 \\
\hline MS at $0.05 \%+\mathrm{CaCl}_{2}$ at $2 \%$ & 1.25 & 1.24 & 2.47 & 2.48 & 1.41 & 1.46 & 0.25 & 0.30 & 2.20 & 2.25 \\
\hline $\mathrm{MS}$ at $0.1 \%++\mathrm{CaCl}_{2}$ at $2 \%$ & 1.40 & 1.40 & 2.52 & 2.55 & 1.45 & 150 & 0.33 & 0.35 & 2.32 & 2.33 \\
\hline $\begin{array}{l}\mathrm{MS} \text { at } 0.025 \%+\mathrm{KCl} \text { at } 2 \% \\
+\mathrm{CaCl}_{2} \text { at } 2 \%\end{array}$ & 1.20 & 1.24 & 2.38 & 2.35 & 1.41 & 146 & 0.24 & 0.28 & 2.18 & 2.18 \\
\hline $\begin{array}{l}\mathrm{MS} \text { at } 0.05 \%+\mathrm{KCl} \text { at } 2 \%+\mathrm{CaCl}_{2} \\
\text { at } 2 \%\end{array}$ & 1.31 & 1.27 & 2.48 & 2.45 & 1.56 & 155 & 0.31 & 0.33 & 2.19 & 2.2 \\
\hline $\begin{array}{c}\text { MS at } 0.1 \%+\mathrm{KCl} \text { at } 2 \%+\mathrm{CaCl}_{2} \\
\text { at } 2 \%\end{array}$ & 1.47 & 1.40 & 2.56 & 2.50 & 1.61 & 158 & 0.35 & 0.37 & 2.27 & 2.32 \\
\hline New L.S.D at $5 \%$ & 0.04 & 0.04 & 0.03 & 0.03 & 0.14 & 0.15 & 0.024 & 0.025 & 0.13 & 0.09 \\
\hline
\end{tabular}

silicon on Fruit chemical properties are in harmony with those obtained by Gad El-Kareem(2012), Al-Wasfy (2014), El-Khawaga (2014), El-Khawaga and Mansour (2014), Gad El-Kareem et al. (2014) and Abd ElWahab (2015).The findings regarding the promoting effect of potassium chloride on Fruit chemical properties are in harmony with those obtained by (Mullins et al., 1992).

\section{N, P, K, Si and Ca contents}

Table (3) showed that carrying out foliar application of micro silica alone or combined with potassium chloride and calcium chloride had significant effects on the percentages of N,P, K, Si and Ca over that of the control treatment. The promotion was obviously related to the increase in concentrations of micro silica. The maximum values were registered on the balady orange trees that were subjected to micro silica at $0.1 \%+$ potassium chloride at $2 \%+$ calcium chloride at $2 \%$ in the two seasons respectively. Control trees gave the lowest values in leaf chemical properties in both seasons. The highest increase in $\mathrm{KCl} \%$ obtained treatments using micro silica at $0.1 \%+$ potassium chloride at $2 \%$ and micro silica at $0.1+$ potassium chloride at $2 \%+$ calcium chloride at $2 \%$ on both seasons. While, the highest value of $\mathrm{Ca} \%$ obtained with treatment using micro silica at $0.1 \%+$ calcium chloride at $2 \%$ and micro silica at $0.1 \%+$ potassium chloride at $2 \%+$ calcium chloride at $2 \%$ on both seasons. The present results dealing with increasing leaf $\mathrm{N}, \mathrm{K}, \mathrm{P}, \mathrm{Ca}$ and $\mathrm{Si}$ could be easily explained as an expected reflection to foliar spray with micro silica was soluble salt source alone or combined with potassium chloride and calcium foliar application is in partial agreement with the results of Lalithya et al., (2014) on Sapota specially N, P, \& K, and Ibrahim and Al-Wasfy ( 2014) on Valencia orange, they mention that potassium chloride silicate spray enhanced overall nutritional status.

\section{CONCLUSION}

The present study it was suggested to spray Balady orange trees with Micro silica at $0.1 \%+$ potassium chloride at $2 \%+$ Calcium chloride $\left(\mathrm{CaCl}_{2}\right)$ at $2 \%$ three times, first spray after fruit set, second spray on the middle of May and the third on middle of July for improving yield and fruit quality.

\section{REFERENCES}

Abd El-Wahab, H.A.M. 2015. Response of Succary mango trees to foliar application of silicon and boron. M.Sc. Thesis Fac. of Agric. Minia Univ. Egypt.

Al-Wasfy, M.M. 2014. The synergistic effects of using silicon with some vitamin on growth and fruiting of Flame seedless grapevines. J. Stem Cell 5(1): 8-13.

A.O.A.C. 1995.Official Methods of Analysis (A.O.A.C) Pub. By official A.O.A.C chapter 4, p.p:18-37, p.p:10-44 p.p:89. 
Chanchal M CH, KCL. RitiThapar and G. Deepak. 2016. Alleviation of abiotic and biotic stresses in plants by silicon supplementation.Sci. Agri.13 (2): 59-73.

Del Amor, F. M. and L. F. M Marcelis. 2003. Regulation of nutrient uptake. water uptake and growth under calcium starvation and recovery. J. Hort. Sci. Biotechnol., 78(3): 343-349.

Egyption Ministry of Agriculture Statistics, 2014. Statistics and Economic Affairs Sector, Ministry of Agric. and Land Reclamation, Egypt.

Elkhatib H. A., S..M. Gabr, A.H. Roshdy and M. M. Abd AlHaleem. 2017. The impacts of silicon and salicylic acid amendments on yield and fruit quality of salinity stressed tomato plants.Alex. Sci. Exch. J.38.933-939.

El-Khawaga, A.S. 2014. Impact of vitamins Band C, glutamic acid and silicon on fruiting of Superior grapevines. World Rural Observations 6(4): 57-62.

El-Khawaga, A.S. and A.G.M. Mansour. 2014. Promoting productivity of Washington Navelorange trees by using some crop seed sproutextracts, silicon and glutathione. Middle East J. of Applied Sciences. 4(3): 779-785.

Epstein E., 1999. Silicon. Annu. Rev. Plant Physiol. Plant Mol. Biol. 50: 641-664.

Gad El- Kareem, M.R., Abdel-Aal, A.M.K. and Mohamed A.Y. 2014. The synergistic effect of using silicon and selenium on fruiting of Zaghloul date palm Phoenixdecty lifera. World Acad. of Sci. Eng. and Tech., Inter. J. Agric. Biosystems Sci. and Engineering 8(3):959-964.

Gad El-Kareem, M.R. 2012. Improving productively of Taimour mango trees by using glutathione, silicon and vitamin B. Minia J. of Agric. Res. \& Develop 32(7): 11051121.

Guntzer F, C. Keller and J.D. Meunier. 2012. Benefits of plant silicon for crops: a review. Agronomy for Sustainable Development. 32:201-213.

Hepler, P.K. 2005. Calcium A central regulator of plan growth and development. The Plant Cell.17 (8): 2142-2155.
Hepler, P.k. and L.J. Winship. 2010. Calcium at the cell wallcytoplast Interface. J. Integr. Plant Biol. 52 (2):147-160.

Horwitz, W., 1972.Official Methods of Analysis Association of Official Analytical Chemists11thed. Washington, D.C.

Kornd?rfer GH and I. Lepsch. 2001. Effect of silicon on plant growth and crop yield. In: Datnoff LE, Snyder GH, Korndorfer GH (eds)Silicon in agriculture Studies in Plant Science, 8. Elsevier, Amsterdam. pp :133-147.

Lalithya, KCL.A., H.P. Bhagya and R. Choudhary. 2014. Response of silicon and micro nutrients on fruit character and nutrient content in leaf of Sapota. J. Biolife, 2(2): 594598.

Ma JF. 2003. Function of silicon in higher plants. Prog . Mol Sub cell Biol. 33:127-147.

Ma JF. 2004. Role of silicon in enhancing the resistance of plants to biotic and abiotic stresses. J. Soil Science and Plant Nutrition. 50(1): 11-18.

Mead, R., R.N. Currnow, and A.M. Harted. 1993. Statistical Methods in Agricultural and Experimental Biology. Second Ed. Chapman \& Hall. London, pp:10- 44.

Meena VD, M. L. Dotaniya, V. Coumar, S. Rajendiran, A.S. Kundu and A.S. Rao. 2014. A Case for Silicon Fertilization to Improve Crop Yields in Tropical Soils. Proc. Natl. Acad. Sci., India, Sect. B Biol. Sci. 84(3):505518.

Mullins, M.G., A. Bouquet and L.E. Williams. 1992. Biology of the Grapevine. Cambridge University Press, New York.

Thippeshappa, G.N., C.S. Ravi and Y.S. Ramesha. 2014. Influence of soil and foliar application of silicon on vegetative characters, fruit yield and nutrients content of sapota leaf. Research on Crops.15(3): 626.

Zaied, N.S., S.A.A. Khafagy, and M.A. Saleh. 2006. Effect of Nitrogen and Potassium chloride fertilization on vegetative growth, fruit set and quality of Washington Navel Orange trees. J. Applied Sciences Research. 2 (11):851-857. 


\section{الملخص العربي}

\section{تطبيق الرش الورقي بالميكرو سيليكون، كلوريد البوتاسيوم وكلوريد الكالسيوم على اشجار البرتقال} البلاى لتحسين المحصول وجودة الثمار

عماد الدين حافظ عبدالعال و محمد احمد حسين حسن

تم إجر اء هذه الدراسة لمعرفة تأثير استخدام الرش بالميكرو سيليكون بمفردة او مشترك مع كل من كلوريد

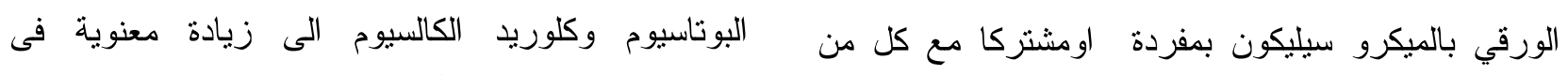



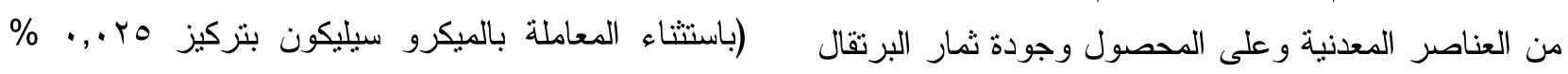

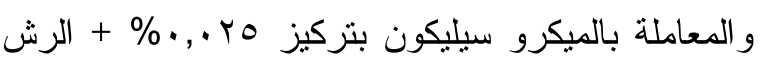

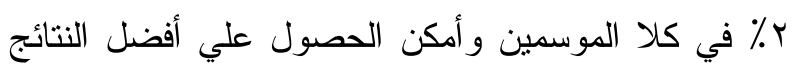

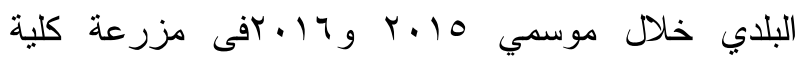
بخصوص كمية المحصول وخصائص الجودة فى أثجار البرتقال البلدى فى التربة الرملية عند رش وش الأشجار



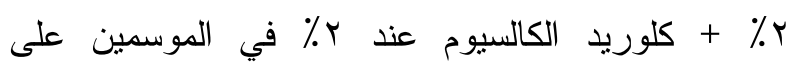
الزر اعة بمنطقة الكو امل سو هاج.

أثنارت النتائج إلى أن رش أشجار البرتقال البلدي بالميكرو سيلكون بمفردة اومشتركا مع كل من كلوريد البوتاسيوم وكلوريد الكالسيوم قد أدى إلى زيادة الإنتاجية

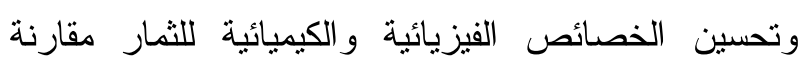

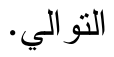
بالمعاملة الكنترول ـ وقد أدت معاملة أثجار البرتقال البلدى ولئي 